\title{
Mode möter Socialism: Modeindustri i Sovjetunionen efter andra världskriget
}

\author{
Jukka Gronow \& Sergey Zhuravlev \\ Helsingfors: Finska litteratursällskapet, 2015 \\ 303 sidor. ISBN 9789522226655
}
Bokrecension av Ekaterina Kalinina [Fil.dr., lektor, Södertörns Högskola, Sverige, ekaterina.kalinina@sh.se]

Denna bok är en efterlängtad systematisk historisk studie av sovjetiska efterkrigstidens mode som i hög grad bidrar till forskningen av postsovjetiska samhället och vardagskultur i synnerhet. Boken berättar om uppkomsten och etableringen av efterkrigstidens sovjetiska modebransch och klädkultur vilket representerar ett försök att förklara orsakerna bakom diskrepansen mellan den propagerade, avancerade modedesignen och den bedrövliga verkligheten av industriellt producerade plagg. Författarna försökte begripa de strukturella och ideologiska förutsättningar som ledde till en situation då de rapida säsongsförändringarna inte passade in i planekonomin. De menade att modet var en viktig del i sovjetiska efterkrigstidens fredliga race med västvärlden eftersom det ansågs vara en viktig del av moderniseringsprojektet.

Baserat på en detaljerad analys av olika arkivmaterial, intervjuer och mediekällor, presenterar boken en omfattande studie av det sovjetiska modesystemet och fokuserar på tre viktiga faktorer som påverkade utvecklingen av den sovjetiska modepolitiska ideologin: den centralt planerade ekonomin och den offentliga åsikten samt inspirationskällorna: modehistoria, internationella trender och folkdräkt. Detta tillvägagångssätt gjorde att författare fokuserade på historia av modeorganisationer som tillhörde olika förvaltningsområden som i sin tur var underordnade för olika ministerier och fanns parallellt: Modehus (Ministeriet för lätt industri), modeateljéer (Handelsdepartementet), verkstäder av skräddarsydda plagg i husen av hushållstjänster (Institution för hushållstjänster). Förutom att belysa dessa tre viktiga strukturella pelare i den sovjetiska modeindustrin nämner och utreder också författarna designoch produktionsaktiviteter som pågick i det stora statliga varuhuset i Moskva - GUM.

Boken innehåller nio kapitel och inleds med en introduktion till bokens viktigaste mål och dess fokus. Kapitel två ger en allmän översikt över utvecklingen av modebranschen och design i mellankrigstidens period och lägger extra uppmärksamhet åt de ideologiska strider som pågick bakom modefasaden. Kapitel tre erbjuder en kort översikt av den sovjetiska ekonomiska utvecklingen, levnadsstandard och materiella kultur i efterkrigstiden. Kapitel fyra följer upp upprättandet av den första institutionen i det sovjetiska modesystemet samt dess utveckling efter kriget. Kapitel fem är tillägnat beskrivningar av hur det komplicerade systemet av parallella 
organisationer och institutioner fungerade med ibland överlappande uppgifter. Det förser en med en intressant berättelse om den roll som designers och andra modefolk spelar. Den lyfter upp ett viktigt dilemma som många designers står inför: Vad var det för syfte med att designa en modern klänning om den aldrig gick vidare till försäljning och fabriker inte var villiga att modernisera sin produktion för att möta de utmaningar som modern design och ökade krav från konsumenterna medförde? Kapitel sex innehåller resultat- och problemanalys av den mest legendariska flaggskeppsbutiken av sovjetisk modedesign - en modeavdelning på det statliga varuhuset GUM som ligger på Röda torget i Moskva. Kapitel sju expanderar geografiska gränser av den sovjetiska modedesignen genom att inkludera historia av Tallinns modehus av det estniska Departementet för lätt industri. Kapitel åtta erbjuder en systematisk analys av sovjetisk modemedia av olika slag. Avsnittet belyser den ideologiska aspekten av sovjetiskt mode genom att presentera diskussioner kring populära modetrender, klädsel och idéer om hygglighet och moral samt kvinnliga och manliga koder. Till exempel tar författarna upp debatten och samhällets reaktion när mini-kjolar blev mode och kvinnor i byxor trängde sig i offentlig miljö.

När det gäller de ideologiska grunderna bakom sovjetiskt mode har författarna dragit följande slutsats: »the official Soviet, socialist aesthetics of dress - and consumption in general - and its maxims of good taste with their emphasis on moderation and harmony were, if anything, petit bourgeois!» (s. 251). Sammanlagt menar författarna att experter och myndigheter kände till de befintliga strukturella problem som genomsyrade produktionen av kläder i Sovjetunionen, men de valde att ignorera dem och att bara ibland ta itu med vissa frågor fast de aldrig tog något fundamentalt beslut för att lösa situationen. Författarna tror också att sovjetisk och västerländsk designvärld har flera kontaktpunkter, som tidigare hade underskattats i olika studier samt av allmänheten i stort. Till exempel pågick processerna av informalisation och individualisering också i Sovjetunionen och stiliagi är ett exempel av detta, även om deras performance tog en måttlig omfattning jämfört med ungdomskulturer i väst. Studien skulle ha tjänat mer detaljerad inblick i modet av hur sovjetiska subkulturer var inkluderade samt gett mer uppmärksamhet åt den stilistiska utvecklingen inom de förändrade föreställningarna om manlighet och kvinnlighet som erbjöds $\mathrm{i}$ Sovjetunionen.

Generellt sett presenteras en detaljerad historisk och sociologisk studie av produktionsprocesser och relationer mellan de olika knutpunkterna av den sovjetiska modebranschen på ett läsarvänligt sätt. En av de stora fördelarna med boken är författarnas kontinuerliga försök att kontextualisera Sovjets mode och att skriva in den i den globala modehistorien och att jämföra dess utveckling med liknande framsteg i väst. Det bör applåderas över ett sådant fascinerande bidrag till Sovjets modehistoria och rekommenderas varmt för läsning. 